\title{
THE LEGAL CONTEXT OF EU COMPETITION LAW DAMAGES ACTIONS
}

I. THE CASE-LAW OF THE CJEU ON REMEDIES

II. THE MOVE FROM RIGHTS TO REMEDIES 1.08

Fixing the boundary between remedial

rules and procedural rules sensu stricto 1.17
III. APPLICATION TO DAMAGES ACTIONS

FOR BREACH OF EU COMPETITION LAW 1.19

\section{THE CASE-LAW OF THE CJEU ON REMEDIES}

1.01 It is a fundamental principle that, while it creates substantive rights and obligations, EU law depends upon the Member States' courts to give effect to those rights and obligations. Thus Member States are said to have autonomy in the matter of remedies and procedures, subject to the twin conditions of equivalence (meaning that the conditions for a claim based on an infringement of EU law may not be stricter than those for a claim based on similar national law) and minimum effectiveness (meaning that the conditions may not render the enforcement of rights granted by the Treaty unduly difficult). These conditions are themselves derived from the general obligation on Member States to ensure the effective application of EU law and comply with the obligations imposed by former Article 10 EC, now Article 4(3) of the Treaty on European Union (TEU). ${ }^{1}$

1 See, for example, Case 33/76 Rewe-Zentralfinanz and Rewe-Zentralv Landwirtschaftskammer für das Saarland (EU:C:1976:188). The tests of equivalence and minimum effectiveness were dropped in some later case law in favour of a higher test of adequacy. This line of case law started with Case 14/83 Von Colson (EU:C:1984:153) and runs through to Case C-271/91 Marshall II (EU:C:1993:375). It should be noted, however, that these cases often deal with the interpretation of EU legislation on equal opportunities, such as Council Directives 76/207/EEC and 79/7/EEC, both of which contain an explicit obligation on Member States to introduce into their legal systems 'such measures as are necessary' to enable all persons who wish to enforce a right under the Directive to be able to 'pursue their claims by judicial process' (Article 6 of both Directives). This explicit remedial provision may help to explain the Court's willingness to raise the test for remedial effectiveness in this line of case law. Later case law shifted back towards the lower minimum effectiveness test, starting from Case C-338/91 Steenhorst-Neerings (EU:C:1993:857) and running through such judgments as Case C-66/95 Sutton (EU:C:1997:207). The point remains however that no matter which test is used, they are all ways of respecting the principle of remedial autonomy of the Member States and reconciling it with the principle of the effet utile of EU law and protection of EU law rights in national courts. 
While EU law therefore provides for common rules of substance, prior to the 1.02 adoption of the Directive, the Union legal order did not provide for substantive or procedural rules for the enforcement of EU competition law in private disputes. Furthermore, the Court of Justice of the European Union (CJEU) does not have jurisdiction for actions brought by a private party against another private party for damages suffered as a result of a breach of EU competition law.

As explained further in Chapter 2.I.A, while the Court of Justice has ruled 1.03 that the right to the recovery of damages in cases of breach of the EU antitrust rules must be guaranteed as a matter of EU law, it has said itself that in the absence of EU legislation in the field, it is for the Member States and their substantive laws to determine the detailed conditions for such a damages claim. ${ }^{2}$

By ruling on references made by national courts, the Court of Justice has 1.04 started to flesh out what the principles of equivalency and effectiveness mean for the bringing of damages claims based on an infringement of EU competition law. ${ }^{3}$ This process will, no doubt, continue.

As in other areas, the Union thus depends on the Member States to provide for effective remedies for, and judicial protection of, rights which are created by EU law. ${ }^{4}$ There is tension between, on the one hand, the coherence of substantive competition law as embodied in Articles 101 and 102 of the Treaty on the Functioning of the European Union (TFEU) and, on the other, the fact that the Union legal order did not have either the procedural or the substantive requirements for granting effective civil redress.

Previously, the creation of remedies in EU law was for the most part confined to ensuring the effective protection of individuals' rights against Member States. There is case-law to this effect in the area of the granting of interim relief while an EU law right is under judicial examination; ${ }^{5}$ restitution for charges levied contrary to a provision of EU law by a Member State; 6 and,

2 Case C-453/99 Courage Ltd v Bernard Crehan (EU:C:2001:465), at para 29.

3 See, for example, Joined Cases C-295/04 to C-298/04 Manfredi v Lloyd Adriatico Assicurazioni SpA (EU:C:2006:461).

4 See, generally, Van Gerven, W, 'Of Rights, Remedies and Procedures' [2000] CMLR 501.

5 Case C-213/89 R v Secretary of State for Transport, ex parte Factortame (Factortame I) (EU:C:1990:257).

6 For example Case 68/79 Hans Just v Danish Ministry for Fiscal Affairs (EU:C:1980:57), Case 199/82 Amministrazione delle Finanze dello Stato v SpA San Giorgio (EU:C:1983:318) and Joined Cases C-192/95 to C-218/95 Société Comateb and others v Directeur Général des Douanes et Droits Indirects (EU:C:1997:12) (cases concerned with the so-called 'defence' of passing-on in this context; briefly, the Court held that the public authority is not required to repay the charges illegally levied if it can show that the trader concerned has passed 
most importantly in the context of litigation for breach of Articles 101 and 102 TFEU, damages for breach of EU law by a Member State. ${ }^{7}$ The Crehan ruling extends this jurisprudence to actions brought by a private party against another private party for breach of EU law, by holding that national courts must under certain circumstances allow individuals to claim damages for breach of EU competition law committed by another individual.

1.07 The idea of EU law remedies in actions against Member States perhaps seems less controversial than that of EU law remedies in actions against private parties. In fact, however, it can be seen that the existence of a remedy in damages against private parties for breach of Articles 101 and 102 TFEU follows from the same principles as give rise to such a remedy against Member States for breaches of other provisions of EU law and is not a revolutionary further step. It is founded on the fact that Articles 101 and 102 TFEU create obligations on, and rights for, individuals, ${ }^{8}$ just as Articles 34 and 49 TFEU, ${ }^{9}$ for example, do against Member States.

\section{THE MOVE FROM RIGHTS TO REMEDIES}

1.08 Statements as to the so-called principle of 'procedural autonomy' do not take into account the difficulty in drawing a precise distinction between rights and remedies, and can be seen to have been exposed as over-simple in the case-law, which has created, to a limited extent at least, remedies as a matter of EU law.

1.09 Articles 101 and 102 TFEU prohibit certain forms of behaviour, and thus impose obligations on undertakings not to behave in certain ways. ${ }^{10}$ Other articles of the Treaty impose obligations on Member States, such as the obligation not to impose quantitative restrictions and measures having equivalent effects (MEQRs) on customs duties on imports contained in Article 34 TFEU, or the obligation not to restrict the freedom to provide services

on the charge to the consumer; in Société Comateb, the Court defined the scope of the 'defence' further, holding at para 27 that it applies where 'the charge has been borne in its entirety by another person and the reimbursement of the trader would constitute unjust enrichment'). See also Case C-188/95 Fantask v Industriministeriet (EU:C:1997:580) (no defence of excusable error to restitution of charges levied contrary to EU law). In general, see Van Gerven, W, loc. cit., 516-21. See also Chapter 3.

7 Joined cases C-6/90 and C-9/90 Francovich v Italian Republic (EU:C:1991:428) and Joined cases C-46/93 and C-49/93 Brasserie du Pêcheur and Factortame III (EU:C:1996:79).

8 Case 127/73 BRT v SABAM (EU:C:1974:6), at para 16.

9 A breach of Article 34 TFEU by Germany was at issue in Brasserie du Pêcheur, and a breach of Article 49 TFEU by the UK in Factortame III.

10 Article 101(1) TFEU prohibits anti-competitive agreements between undertakings, while Article 102 TFEU prohibits abuses of a dominant position by undertakings. 
contained in Article 56 TFEU. Certain articles directly give rights to individuals, such as the right to free movement of workers and certain other specific rights flowing from that contained in Article 45 TFEU, especially Article 45(3) TFEU. In fact, Articles 101 and 102 TFEU are almost unique in the Treaty in that they impose obligations not on Member States but on private legal individuals, undertakings. ${ }^{11}$

The question becomes: what further rights flow from the rights and obligations created with respect to undertakings and Member States by the Treaty? The question is of significance because it is not always possible to draw a sharp distinction between rights and remedies. It can be argued that harmonisation of certain conditions relating to remedies in actions for the enforcement of EU law is no more than a necessary consequence of the fact that the Treaty creates in one way or another obligations and rights for individuals and Member States. Harmonisation of remedies in the area of Articles 101 and 102 TFEU therefore, like the harmonisation of remedies in other areas, does not as a general rule offend against the principle of the autonomy of Member States in matters of remedies and procedure. ${ }^{12}$

When a right or an obligation is created by law, then, in order for it to have 1.11 any effective legal existence, the individuals for whose benefit it has been created must be able to enforce it before a court of law. ${ }^{13}$ This means not only that such individuals must have access to a court, but also that they must have access to a class of action designed to protect that right.

Within the scheme of the European Convention for the Protection of Human 1.12

Rights and Fundamental Freedoms (ECHR), access to a court is guaranteed under Article 6 (right to a fair trial), while access to an appropriate class of action is guaranteed under Article 13 (right to an effective remedy). As a matter of Union law, ${ }^{14}$ both rights are recognised by Article 47 of the Charter

11 Cf. also Article 157 TFEU ('equal pay ... for equal work or work of equal value'); see Case 43/75 Defrenne v Sabena (EU:C:1976:56).

12 There are certain exceptions to this general rule, of course. Exemplary damages are, for example, deemed to run counter to public policy in Germany, while in the same jurisdiction, an opt-out system of collective redress is unconstitutional (see further Chapter 7.IV and Chapter 11 respectively).

13 In Francovich, the Court articulates the idea of the effective legal existence of a right or obligation in terms of the obligation on national courts to 'protect the rights which [the provisions of EU law] confer on individuals' (para 32) and the 'full effectiveness of Community rules' (para 33) and thus finds it to be 'inherent in the system of the Treaty' (para 35). It also derives it specifically from Article 4(3) TEU, former Article $10 \mathrm{EC}$ (para 36). This is repeated by the Court in Brasserie du Pêcheur at para 39. Van Gerven, loc. cit. uses 'uniform application' of EU law as the underpinning principle for his arguments in favour of a certain harmonisation of remedies.

14 See the first subparagraph of Article 6(1) TEU. 
of Fundamental Rights of the European Union..$^{15}$ In accordance with Article 6(3) TEU, they have been interpreted by the Court as general principles of EU law, ${ }^{16}$ being based, inter alia, on the common constitutional traditions of the Member States.

1.13 For example, if a legislative measure says that the seller is entitled to recover the price of goods delivered to the buyer but not paid for, then for that right to exist effectively, the seller must be able to take the buyer to court and request that the money be paid to him. Another example might be a law in the field of non-contractual obligations. Such a law might provide, either in legislation or judge-made law, that if A negligently drives his car in such a way as to cause damage to $B$, then $B$ is entitled to demand from $A$ payment to make up for such damage as he may have suffered. Thus $B$ in this set of circumstances needs to have access to some sort of action for payment in order effectively to enforce A's obligation towards the world to drive carefully.

1.14 It should be noted at this point that a law can be enforced in different ways according to whether it confers rights or imposes obligations. In the example of the buyer and the seller, or Article 45(3) TFEU, the legislative measure explicitly confers a right of recovery of the purchase price on the seller (this could be called a 'direct' right). It is a positively expressed, facilitative law which creates by implication a corresponding obligation on the buyer to pay the purchase price. Following from this, it can be said that there exists also a sort of 'secondary' right of the seller to enforce that 'direct' right against the buyer in a court of law when the necessary conditions for the 'direct' right to arise have been shown to have been fulfilled. ${ }^{17}$ This secondary right could be called a 'right to enforce'18 and is closely connected to the seller's remedy. To say that a right has to be enforceable through a legal remedy is very close to saying that the injured party has another 'right' to that remedy; in fact, the

15 OJ C 303, 14.12.2007, p. 1. See the accompanying explanation for reference to the relevant provisions of the ECHR. As noted in the explanation, the protection afforded by the Charter is more extensive, since it refers to access to an effective remedy before a 'court', while Article 13 of the ECHR refers to an effective remedy before a 'national authority'.

16 See, for example, the judgment of 15 May 1986 in Case 222/84 Johnston v Chief Constable of the Royal Ulster Constabulary (EU:C:1986:206), at para 18, and the judgment of 15 October 1987 in Case 222/86 Unectef v Heylens and others (EU:C:1987:442), at para 14. These rulings are referred to in the explanation on the first paragraph of Article 47 of the Charter.

17 Eilmansberger, T, 'The Relationship between Rights and Remedies in EC Law: In Search of the Missing Link' [2004] CMLR 1199, at $1238 \mathrm{ff}$. uses a similar schema ("primary obligations/rights' and 'secondary obligations/rights').

18 Thus the Court in Francovich at para 38 speaks of a 'right to reparation' and in Brasserie du Pêcheur at para 67 of 'the right to reparation which flows directly from Community law'. 
confusion in terminology (describing what is essentially a remedy in terms of a right) can be seen to show how closely bound remedies are to pure rights and obligations.

In the example of the driver, the law does not directly confer any right on $\mathrm{B}$ but instead imposes an obligation on A. It is a negatively expressed, prohibitive law, as are most of the articles of the Treaty, including Articles 34, 56, 101 and 102 TFEU. The question then is how to analyse the operation of this obligation in terms of 'direct' rights, 'rights to enforce' and remedies. The jurisprudence of the Court as expressed in such judgments as Van Gend en Loos and Francovich states that rights in EU law can arise expressly under provision of the Treaty, but also as a result of obligations imposed by the Treaty upon individuals, Member States or the EU institutions. Thus rights can arise by implication from the existence of obligations. In the factual scenario of Van Gend en Loos, the right flowing from the obligation contained in Article 34 TFEU would be the right to move goods across national borders without having to pay customs duties. This type of right may be similar to a 'direct' right, although it is not directly imposed by the law itself. It is certainly more substantive than a 'right to enforce' and distinguishable from the remedy required to protect it. The 'right to enforce' that right through a legal remedy then arises at a further, though necessarily consequential, stage.

The example of the driver is somewhat different. It is very difficult to express any 'right' for B which flows from the obligation on A without referring to a remedy sought by B. B's 'right' in this situation is to have such damage as is caused to him by A made good by A. ${ }^{19}$ In this situation there does not seem to be an intermediate right arising from the obligation imposed in the way identified by the Court in Van Gend en Loos and Francovich. Instead, the only 'right' which exists is B's 'right to enforce' A's obligation against him. In this case, the link between rights and remedies is even closer and when a court speaks of protecting the rights of individuals, in such a situation it can only be referring to the protection of a 'right' to a remedy, that is, the remedy itself.

\section{Fixing the boundary between remedial rules and procedural rules sensu stricto}

Van Gerven ${ }^{20}$ differentiated between, on the one hand, the 'constitutive' conditions of the remedy, which are the same as the 'substantive' conditions for the underlying right to arise, and on the other hand, 'executive' remedial rules,

19 Cf. Article 1240 of the French Code civil: 'Tout fait quelconque de l'homme, qui cause à autrui un dommage, oblige celui par la faute duquel il est arrivé à le réparer.'

20 Loc. cit., especially 524-25. 
which are required to implement the 'constitutive' elements of the remedy. ${ }^{21}$ He therefore distinguished between two different types of remedial rule, the former which arise as a necessary consequence of the existence of the right in the way outlined above, and the latter which are closer to pure procedural rules. He argued that it is necessary to have complete harmonisation of the former in order to complement the existence of substantive EU law rights which must be the same throughout the Union; while in the case of the latter it is necessary only that they obey the adequate protection principle. $\mathrm{He}$ suggested that this would strike an appropriate balance between the need for a certain harmonisation of remedies, and respect for the traditional principle of the autonomy of Member States in terms of remedies and procedures.

1.18 The scheme Van Gerven proposed is, however, not always consistent. In his draft proposal for a harmonising regulation, ${ }^{22}$ he appeared to include in the regulation issues relating to the 'form and extent' of the remedy, such as the heads of damage which can be recovered, which were described as 'executive' rules in the earlier paper, which suggests perhaps that he no longer wished to insist on this distinction. It would seem that such a distinction is not only hard to make, but also might restrict the scope of harmonisation unduly, since it is precisely rules of an 'executive' character, such as heads of damage rules, standing rules and rules on interest, which also need harmonisation in order to promote as much as possible harmonised private enforcement of the competition rules before national courts. It is not enough simply to assert that an EU law remedy of damages for breach of Articles 101 and 102 TFEU must exist as a matter of principle without also fleshing out that remedy in any harmonising legislation in order to ensure precisely that, as far as possible, such harmonisation of remedies has as much practical impact as possible throughout the Union.

\section{APPLICATION TO DAMAGES ACTIONS FOR BREACH OF EU COMPETITION LAW}

1.19 Whenever a legal system creates an obligation or a right, by necessity there must also arise an effective means for the injured party to enforce compliance

21 This distinction corresponds to that between the so-called 'remedial' aspects of the civil law governing damages claims for breach of EU competition law, and the purely procedural aspects. The former will be determined by the civil law applicable to the claim, while the latter will be the law of the forum hearing the claim.

22 Van Gerven, W, 'Substantive Remedies For the Private Enforcement of EC Antitrust Rules Before National Courts', in European Competition Law Annual 2001: Effective Private Enforcement of EC Antitrust Law (Ehlermann, C-D and Atanasiu, I (eds), Hart, Oxford/Portland, 2003), at 53, 90 (Annex 2). 
with the behaviour required ('right to enforce'), whether that is a right to enforce a 'direct' right imposed by a facilitative, positively expressed law, or the right to enforce an obligation imposed by a prohibitive, negatively expressed law against another party. This means could be recovery of compensation (or damages) or performance of a (contractual) obligation. Specific performance and damages are usually classed as 'remedies', and while this classification may have its uses, it can be seen that remedies at least in this sense arise as a necessary consequence of the creation of a legal right or obligation, once the (separate) right of access to a court is added. This must be the case, or else the right would have no effective legal existence. These arguments apply equally to all obligations and rights created by the Treaty, regardless of whether they are obligations imposed on Member States or on private undertakings.

Therefore a single remedy or set of remedies as a matter of EU law for private enforcement actions under Articles 101 and 102 TFEU need not be seen as a major legal revolution. To the extent that the existence and extent of such remedies have been, and will be, clarified by legislation or by case-law of the CJEU, such developments are doing little more than, in the first instance, making explicit something which must arise from Articles 101 and 102 TFEU. 